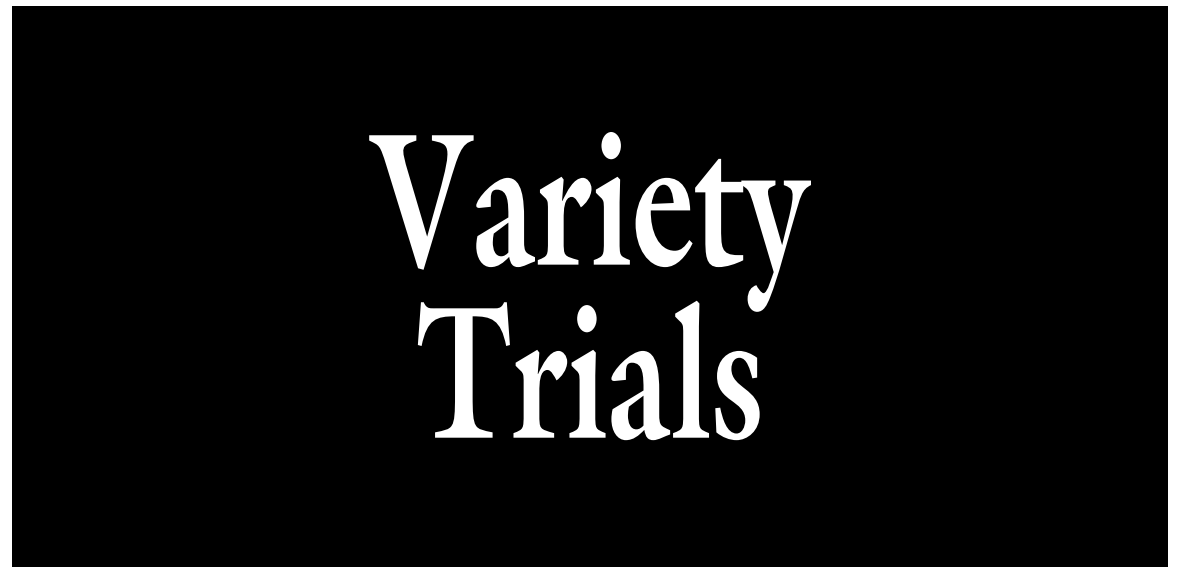

\section{Edible-pod Peas as High-value Crops in the U.S. Virgin Islands}

\author{
Rhuanito S. Ferrarezi ${ }^{1}$, Stuart A. Weiss, Thomas C. Geiger, \\ and K. Paul Beamer
}

ADDITIONAL INDEX WORDS. snow pea, sugar snap pea, cultivar trial, tropics, food security, cropping system

Summary. Snow pea (Pisum sativum var. saccharatum) and sugar snap pea ( $P$. sativum var. macrocarpon) are high-value crops typically grown in temperate regions. Temperature is the main limiting factor to growing edible-pod peas in warmer U.S. states and territories. The objective was to evaluate edible-pod peas performance in tropical climates and to make cultivar recommendations to farmers in the U.S. Virgin Islands based on fruit yield. Trials were performed in two consecutive years (2014 and 2015), testing six cultivars of edible-pod peas: three snow pea (Little Sweetie, Mammoth Melting, and Oregon Giant) and three sugar snap pea (Super Sugar Snap, Cascadia, and Sugar Sprint) in a complete randomized block with four replications. 'Little Sweetie' produced the highest total fruit yield for the season $\left(15,442 \mathrm{~kg} \cdot \mathrm{ha}^{-1}\right)$ and 'Mammoth Melting' $\left(4249 \mathrm{~kg} \cdot \mathrm{ha}^{-1}\right)$ and 'Sugar Sprint' (3349 $\left.\mathrm{kg} \cdot \mathrm{ha}^{-1}\right)$ produced the lowest total fruit yield in Year 1 . The same trend happened in Year 2, where 'Little Sweetie' $\left(14,322 \mathrm{~kg} \cdot \mathrm{ha}^{-1}\right)$ and 'Super Sugar Snap' $\left(12,511 \mathrm{~kg} \cdot \mathrm{ha}^{-1}\right)$ were higher yielding and 'Mammoth Melting' (4582 $\left.\mathrm{kg} \cdot \mathrm{ha}^{-1}\right)$ and 'Sugar Sprint' (1929 $\mathrm{kg} \cdot \mathrm{ha}^{-1}$ ) were the lowest yielding cultivars. 'Mammoth Melting' showed a marketable yield below $80 \%$ of total yield in Years 1 and 2. 'Mammoth Melting' and 'Super Sugar Snap' produced the tallest plants in Year 1, while 'Mammoth Melting' was significantly taller than the others in Year 2. As expected, sugar snap pea presented fruit soluble solids concentration (SSC) $2.7 \%$ to $6.5 \%$ higher than snow pea. The snow pea cultivars had longer mean fruit length $(81$ to $86 \mathrm{~mm})$ than sugar snap pea $(60$ to $68 \mathrm{~mm})$. The opposite trend occurred with fruit thickness; sugar snap pea averaged $28.5 \%$ thicker than snow pea. The shoot dry weight of 'Sugar Sprint' was on average $78.5 \%$ smaller than 'Mammoth Melting' and 'Oregon Giant', resulting in poor performance due to small plant size. 'Mammoth Melting' and 'Super Sugar Snap' had the lowest chlorophyll content compared with the other cultivars. Results of this experiment indicate that ediblepod peas have potential as a specialty, short-season, high-value crop when grown in the cool-dry winter months of the U.S. Virgin Islands. Of the cultivars tested, Little Sweetie was the highest yielding cultivar evaluated within the environmental and geographical conditions of this study for two consecutive years.

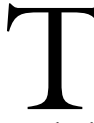
he most important difference between the types of green pod pea ( $P$. sativum) is the pod shape at harvest (De Ron et al., 2005). English pea (P. sativum var. sativum) has fibrous pods that are shelled before processing (Strang et al., 2011). Snow pea (thin walls) has flat pods that are harvested when the pods have reached full size but before seeds have developed. Sugar snap pea (thick pod walls) has round pods that are harvested after seed development (Gross et al., 2014). In terms of flavor, texture, growth, and yield, they are very similar. For this reason, we will discuss the snow and sugar snap pea cultivars tested as simply edible-pod peas.

Edible-pod peas are an alternative crop for small farmers due to the short cycle, high yield, and high value of produce (Kahn and Nelson, 1991). Fresh peas could enhance small farm revenue by providing increased produce diversity, higher profitability, and specialty crop interest to direct market consumers. The main limitation for extensive production areas is the intensive use of labor since the crop requires constant harvesting (Kahn and Nelson, 1991).

Most cultivars of edible-pod peas reach maturity around $60 \mathrm{~d}$ after planting (DAP). Edible-pod peas are an annual crop propagated from seed. They are typically grown in temperate states, such as California, Kentucky, Oregon, and New York, with optimum growing temperature between 55 and $65^{\circ} \mathrm{F}$ (Gaskell, 1997). Ediblepod peas can be produced during cool growing seasons (De Ron et al., 2005) and could therefore become a specialty crop for tropical and subtropical regions during seasonally cool months.

There is no information regarding edible-pod pea cultivation in the U.S. territories, especially the U.S. Virgin Islands. The performance of different cultivars should be evaluated under various environmental conditions (De Ron et al., 2005) since cultural information is scarce and the crop has a potential as an alternative crop for small farmers (Kahn and Nelson, 1991). Vegetable performance trials are still essential to vegetable growers to maximize the return and increase farm crop diversity (Williams and Roberts, 2002). Data on fresh edible-pod peas wholesale prices and on the quantity of fresh peas consumed in the U.S. Virgin Islands are also unavailable. Wholesale prices in Miami, FL, which presents the most similar climate, range from $\$ 12$ to $\$ 13$ for a 10-lb carton (USDA, 2015a). Local food production is encouraged to reduce reliance on food imports and keep food dollars in the local economy. One current trend in the local food movement is community-supported agriculture and farmers' market stands. Increased consumer awareness and demand could eventually lead to higher volume markets (e.g., grocery stores) 
and direct marketing to restaurants interested in serving high-quality, locally produced vegetables.

The optimal time to grow ediblepod peas in the U.S. Virgin Islands would be during the cool and dry months from November through March (Intellicast, 2015). Temperatures higher than $80^{\circ} \mathrm{F}$ are tolerated during vegetative growth but will encourage rapid fruit development, which can reduce yield and fruit quality, especially if harvests are not performed every 2 or $3 \mathrm{~d}$. Planting during the rainy season can reduce the need for irrigation, but high humidity and frequent rains increase disease and pest pressure in general (Gaskell, 1997).

The objective was to evaluate the performance of edible-pod peas in tropical climates, and to make cultivar recommendations to farmers in the U.S. Virgin Islands based upon fruit yield from two consecutive years.

\section{Materials and methods}

LOCATION AND ENVIRONMENTAL CONDITIONS. Edible-pod peas were evaluated at the same field on $4 \mathrm{Feb}$. 2014 (Year 1) and 30 Jan. 2015 (Year 2 ) at the University of the Virgin Islands Agricultural Experiment Station (UVI AES), Kingshill, U.S. Virgin Islands (lat. $17^{\circ} 43^{\prime} 08^{\prime \prime} \mathrm{N}$, long. $64^{\circ} 47^{\prime} 46^{\prime \prime} \mathrm{W}, 100 \mathrm{ft}$ elevation). UVI AES is located on the island of St. Croix, which is the largest of three primary U.S. Virgin Islands. The territory presents an equatorial climate with dry summers (As) according to Köppen-Geiger classification (Kottek et al., 2006). St. Croix is characterized as having a tropical/subtropical environment with annual rainfall averages of $1041 \mathrm{~mm}$ and a mean monthly temperature range of 72 to $91{ }^{\circ} \mathrm{F}$. Rainfall patterns exhibit interannual variability with an initial early rainy season beginning in May

\footnotetext{
Agricultural Experiment Station, University of the Virgin Islands, RRI Box 10,000, Kingshill, VI 00850

Funding for this research was provided by USDANIFA-Hatch Funds (accession no. 227355).

We thank Paulino Perez and Victor Almodovar (Horticulture and Aquaculture program), Jose Herrera and Nelson Benitez (Agronomy program), and the undergraduate students Shamali Dennery and Kalunda Cuffy for their technical assistance. We also thank Robert Godfrey and Thomas Zimmerman for their thorough and critical review of our manuscript.

${ }^{1}$ Corresponding author. E-mail: rhuanito.ferrarezi@ uvi.edu.
}

doi: 10.21273/HORTTECH03438-16 that can extend into June, then a dry period in July and August followed by the primary rainy season from August to November (concurrent with the Atlantic hurricane season); and finally an extended dry season that runs from December/January into May (Gonzales et al., 2007; USDA, 1998). Highest temperatures occur in August-October, and the lowest in January-February. The annual mean temperature on St. Croix is $83^{\circ} \mathrm{F}$ (Godfrey and Hansen, 1996).

Daily rainfall, air temperature, relative humidity, and solar radiation were recorded throughout the studies using a weather station from the USDA National Water \& Climate Center, Natural Resources Conservation Service (USDA, 2015c). The equipment was located $50 \mathrm{~m}$ from the experiment site. The following measurements were calculated for the two experimental growing seasons in 2014 (Year 1 ) and 2015 (Year 2), respectively: total rainfall averaged 198 and $87 \mathrm{~mm}$; air temperature averaged $( \pm \mathrm{SE}) 24.86 \pm$ 0.09 and $25.44 \pm 0.10{ }^{\circ} \mathrm{C}$; relative humidity averaged $85.61 \% \pm 0.62 \%$ and $81.01 \% \pm 0.54 \%$; the vapor pressure deficit was calculated from the saturated and actual air vapor pressure using the air temperature and relative humidity data, and averaged $0.46 \pm$ 0.02 and $0.62 \pm 0.02 \mathrm{kPa}$; and daily solar radiation averaged $19.98 \pm 0.48$ and $18.79 \pm 0.44 \mathrm{MJ} \cdot \mathrm{m}^{-2}$ (Fig. 1).

The soil on the experimental site is a Sion clay $(\mathrm{SiB})$ according to the USDA soil survey (USDA, 2015b). Soil nutrient concentration was evaluated $21 \mathrm{~d}$ prior to edible-pod peas seeding on each block before planting on Year 2 (9 Jan. 2015); average soil $\mathrm{pH}=7.5$, soluble salts $=0.3 \mathrm{dS} \cdot \mathrm{m}^{-1}$, organic matter $=3.1 \%$, and nutrient concentrations $\left(\mathrm{mg} \cdot \mathrm{L}^{-1}\right)$ : nitratenitrogen $=14.0$, phosphorus $=$ 12.5 , potassium $=237.5$, calcium $=$ 20,081 , magnesium $=295$, sulfur $=37.8$, boron $=1.2$, copper $=2.1$, iron $=$ 19.5, manganese $=19.8$, zinc $=1.9$, and sodium $=43$. No data are available for Year 1 .

Treatments and eXPerimental DESIGN. We tested six different cultivars of edible-pod peas: three snow pea [Little Sweetie, Mammoth Melting, and Oregon Giant (described by Baggett and Kean, 1992)] and three sugar snap pea [Super Sugar Snap, Cascadia (described by Baggett and Kean, 1993), and Sugar Sprint]. 'Sugar Sprint' and 'Super Sugar Snap' seeds were procured from Twilley Seed (Hodeges, SC), 'Mammoth Melting' from Willhite Seed Inc. (Poolville, TX), and 'Little Sweetie', 'Oregon Giant', and 'Cascadia' from Stokes Seed Co. (Buffalo, NY). The experimental design was a complete randomized block with four replications in both studies (Years 1 and 2).

Growing Conditions. The experimental area was managed using cover crops preceding pea planting. In Year 1 , the experimental field was planted in 'IAC-1' sunn hemp [Crotalaria juncea (800,000 plants/ha)] in Aug. 2013; followed by 'Rongai' lablab [Lablab purpureus $(400,000$ plants/ha)] planted in Nov. 2013. In Year 2, the experimental field was planted with a cover crop mix of sunn hemp, 'Hyb.' sesame (Sesamum indicum), and 'Black Oil' sunflower (Helianthus annuus) in Oct. 2014. The plant population was $500,000,100,000$, and 50,000 plants/ha, respectively. Sunn hemp and lablab seeds were inoculated

\begin{tabular}{llll}
\hline $\begin{array}{l}\text { Units } \\
\text { To convert U.S. to SI, } \\
\text { multiply by }\end{array}$ & U.S. unit & SI unit & $\begin{array}{l}\text { To convert SI to U.S., } \\
\text { multiply by }\end{array}$ \\
\hline 0.4047 & acre $(\mathrm{s})$ & $\mathrm{ha}$ & 2.4711 \\
0.3048 & $\mathrm{ft}$ & $\mathrm{m}$ & 3.2808 \\
0.0283 & $\mathrm{ft}^{3}$ & $\mathrm{~m}^{3}$ & 35.3147 \\
3.7854 & gal & $\mathrm{L}$ & 0.2642 \\
2.54 & inch $(\mathrm{es})$ & $\mathrm{cm}$ & 0.3937 \\
25.4 & inch $(\mathrm{es})$ & $\mathrm{mm}$ & 0.0394 \\
0.0418 & langley(s) & $\mathrm{MJ} \cdot \mathrm{m}^{-2}$ & 23.9006 \\
0.4536 & lb & $\mathrm{kg}$ & 2.2046 \\
1.1209 & lb/acre & $\mathrm{kg} \cdot \mathrm{ha}^{-1}$ & 0.8922 \\
0.0254 & mil & $\mathrm{mm}$ & 39.3701 \\
1 & $\mathrm{mmho} / \mathrm{cm}$ & $\mathrm{dS} \cdot \mathrm{m}^{-1}$ & 1 \\
28.3495 & $\mathrm{oz}$ & $\mathrm{g}$ & 0.0353 \\
30.5152 & $\mathrm{oz} / \mathrm{ft}^{2}$ & $\mathrm{mg} \cdot \mathrm{cm}^{-2}$ & 0.0328 \\
1 & $\mathrm{ppm}$ & $\mathrm{mg} \cdot \mathrm{L}^{-1}$ & 1 \\
6.8948 & $\mathrm{psi}$ & $\mathrm{kPa}$ & 0.1450 \\
$\left({ }^{\circ} \mathrm{F}-32\right) \div 1.8$ & ${ }^{\circ} \mathrm{F}$ & ${ }^{\circ} \mathrm{C}$ & $\left({ }^{\circ} \mathrm{C} \times 1.8\right)+32$
\end{tabular}



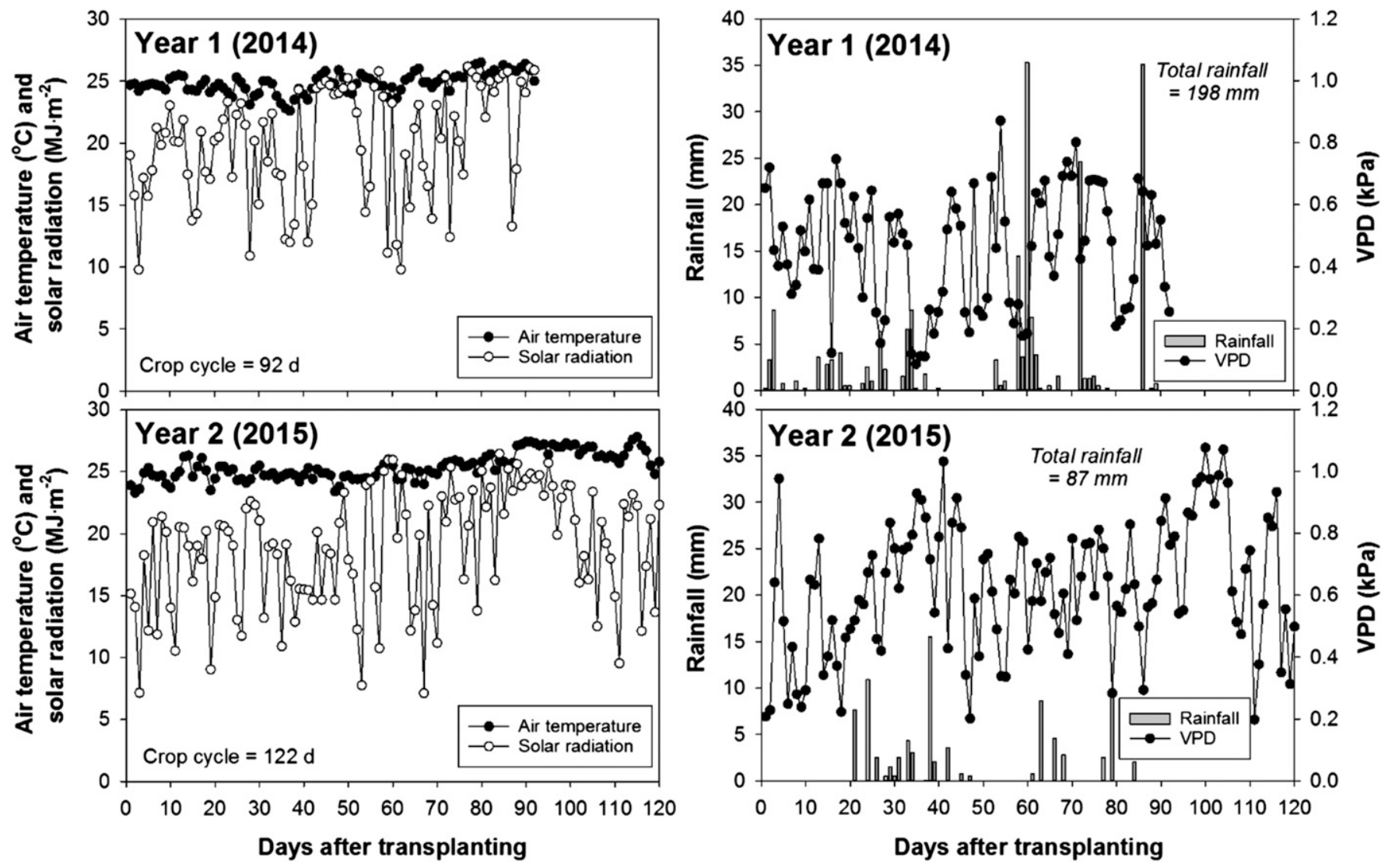

Fig. 1. Air temperature, solar radiation, rainfall, and vapor pressure deficit (VPD) over the 2 years (2014 and 2015$)$ of experiments performed in Kingshill, U.S. Virgin Islands. $\left({ }^{\circ} \mathrm{C} \times 1.8\right)+32={ }^{\circ} \mathrm{F}, 1 \mathrm{MJ} \cdot \mathrm{m}^{-2}=0.0418$ langley, $1 \mathrm{~mm}=0.0394$ inch, $1 \mathrm{kPa}=0.1450$ psi.

before planting with Bradyrbizobium sp. inoculant. The cover crops were terminated in Years 1 and 2 at 90 DAP with a rotary mower/shredder, followed by residue soil incorporation with a disk harrow. Fine seed bed preparation was completed by two passes with a roto-tiller $8 \mathrm{~d}$ prior to planting in both years.

Pea cultivars were hand seeded directly into the ground on $4 \mathrm{Feb}$. 2014 (Year 1) in double rows with 3 -inch in-row spacing and $3 \mathrm{ft}$ between double-row centers for a stand of 287,037 plants/ha. On 30 Jan. 2015 (Year 2) pea cultivars were hand seeded on a staggered single row with 4 -inch in-row spacing and $3 \mathrm{ft}$ between row centers for a stand of 107,639 plants/ha. This plant population adjustment in Year 2 was performed to facilitate hand harvesting, based on results from Year 1 and on the description of De Ron et al. (2005), who recommends 125,000 plants/ha. Seeds were inoculated before planting with Rhizobium leguminosarum biovar viceae inoculant to ensure root nodule formation (Pavek,
2012). Each experimental unit had three 6-m-long rows and data were collected from the center row in each plot. Plants were trained on $1.5 \mathrm{~m}$ tall $\times$ $0.15 \mathrm{~m}$ apart quadrangular plastic trellises (Hortonova 10FG; Tenax, Baltimore, MD) installed on the length of the row between metal T-posts at $3-\mathrm{m}$ intervals for plant support. Edible-pod peas are usually cultivated on trellises to hand harvest the pods (Kahn and Nelson, 1991). However, short snap pea cultivars are developed for field production without trellis to allow for over the top mechanical harvest.

In Year 1, plots were irrigated daily based on visual observations. In Year 2, irrigation scheduling was determined by a weather-based method using calculated evapotranspiration (Harmsen, 2012). On both years, irrigation was applied using a $5 / 8$ inch-diameter and 8-mil-thick drip lines with 0.2 -gal $/ \mathrm{h}$ emitters spaced every 4 inches (Aqua-Traxx, Bloomington, MN). A total of 60 and $100 \mathrm{lb} /$ acre nitrogen was applied in Years 1 and 2 , respectively, using $20 \mathrm{~N}$ 8.7P-16.3K soluble fertilizer (Jack's
Professional; JR Peters, Allentown, PA) through a fertilizer injector (D45RE15; Dosatron, Clearwater, FL). A 4-inch-thick layer of hay mulch was applied 36 DAP (Year 1) and 24 DAP (Year 2) for weed suppression, to reduce soil surface temperature, and to minimize soil moisture loss.

The field was scouted for insect pests and plant diseases weekly until first harvest and then at every harvest. Lepidopterans (Lepidoptera) were controlled using Bacillus thuringiensis (DiPel DF; Valent Biosciences, Walnut Creek, CA) and stink bugs (Pentatomidae) were controlled using a pyrethrin-based spray (PyGanic Crop Protection EC 1.4II; McLaughlin Gormley King, Minneapolis, MN). Weeds were manually controlled at 15 , 36 , and $56 \mathrm{DAP}$ (Year 1) and at 19,27, and $49 \mathrm{DAP}$ (Year 2).

Measurements. Seed germination was evaluated, and ranged from $87.5 \%$ to $100 \%$ on both years (data not shown). Harvests were performed on a semiweekly basis on $57,62,65$, $69,72,76,79,82,85$, and $90 \mathrm{DAP}$ for a total of 6 weeks with 10 harvest 
Table 1. Analysis of variance for total and marketable fruit yield, plant height and soluble solids concentration for 2 years (2014 and 2015) and six cultivars of edible-pod peas [ three snow pea (Little Sweetie, Mammoth Melting, and Oregon Giant) and three sugar snap pea (Super Sugar Snap, Cascadia, and Sugar Sprint)].

\begin{tabular}{|c|c|c|c|c|c|c|c|}
\hline \multirow{2}{*}{ Factor } & \multirow{2}{*}{\multicolumn{2}{|c|}{ Fruit yield }} & \multicolumn{3}{|c|}{ Plant ht } & \multicolumn{2}{|c|}{ Soluble solids concn } \\
\hline & & & $\begin{array}{c}56^{z} \text { and } 53^{y} \\
D^{y A P^{x}}\end{array}$ & $\begin{array}{c}76^{\mathrm{z}} \text { and } 73^{\mathrm{y}} \\
\text { DAP }\end{array}$ & $\begin{array}{c}85^{z} \text { and } 90^{y} \\
\text { DAP }\end{array}$ & $\begin{array}{c}72^{\mathrm{z}} \text { and } 73^{\mathrm{y}} \\
\text { DAP }\end{array}$ & $\begin{array}{c}82^{\mathrm{z}} \text { and } 87^{\mathrm{y}} \\
\text { DAP }\end{array}$ \\
\hline Model & $<0.0001$ & $<0.0001$ & $<0.0001$ & $<0.0001$ & $<0.0001$ & $<0.0001$ & 0.0551 \\
\hline Cultivar & $<0.0001$ & $<0.0001$ & $<0.0001$ & $<0.0001$ & $<0.0001$ & 0.1090 & 0.0248 \\
\hline Year $\times$ Cultivar & 0.0326 & 0.0267 & 0.8341 & 0.8244 & 0.7017 & 0.3275 & 0.3877 \\
\hline
\end{tabular}

z2014 (Year 1).

y2015 (Year 2).

${ }^{x}$ Days after planting.

${ }^{\mathrm{w}}$ Coefficient of variation.

events in Year 1 ; and on 52, 56, 59, $61,66,70,75,77,81,84,87,90,94$, and 97 DAP for a total of 7 weeks with 14 harvest events in Year 2. We quantified the cumulative production to determine total and marketable yield (Years 1 and 2 ). We also determined plant height at 57, 76, and 86 DAP (Year 1 ) and 53,73, and $90 \mathrm{DAP}$ (Year 2 ) in 10 random plants per plot; and fruit SSC at 72 and 82 DAP (Year 1) and 73 and 87 DAP (Year 2) using a refractometer (RF15; Extech Instruments, Nashua, $\mathrm{NH})$. Fruit SSC was sampled three times per plot with three fruit in each sample.

In Year 2, we also determined fruit size (length, thickness, and weight) in 10 fruit per plot; and shoot dry weight and chlorophyll content using a portable meter (atLEAF; FT Green, Wilmington, DE) in three samples per plot. We monitored the soil volumetric water content using four capacitance sensors (10HS; Decagon Devices, Pullman, WA) connected to a low-cost open-source microcontroller (Mega; Arduino, Ivrea, Italy). We used one sensor per block. System assembling followed Ferrarezi et al. (2015). Measurements ranged from 0.35 to $0.5 \mathrm{~m}^{3} \cdot \mathrm{m}^{-3}$ (data not shown).

Statistical analysis. Data were analyzed using general linear model procedures in SAS (version 9.4; SAS Institute, Cary, $\mathrm{NC}$ ) using a one-way analysis of variance model to test the six edible-pod pea cultivars. Probability values $\leq 0.05$ were considered statistically significant.

\section{Results and discussion}

There were significant differences in total and marketable fruit yield for year and cultivar interaction

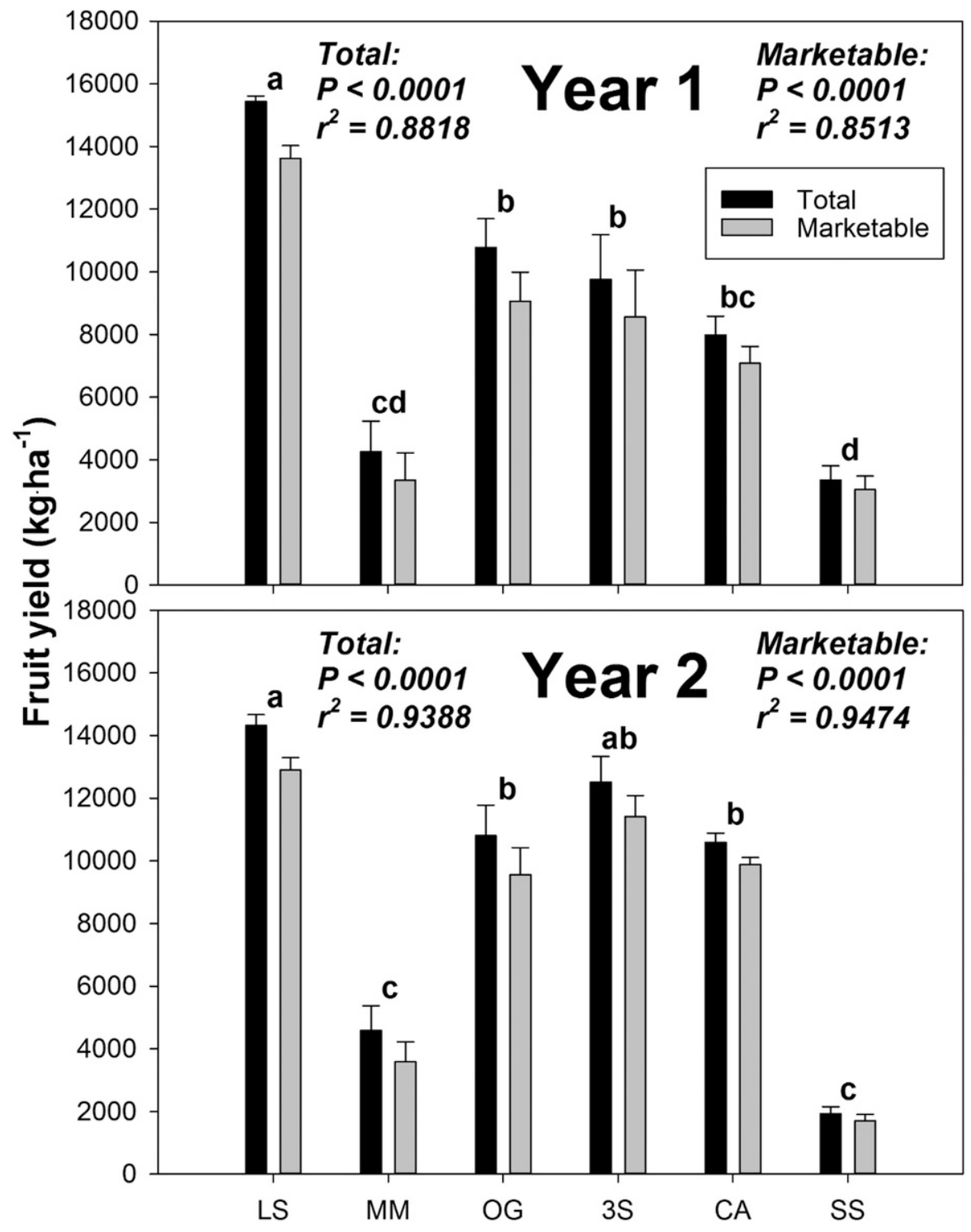

Fig. 2. Total and marketable fruit yield of six cultivars of edible-pod peas \{three snow pea [Little Sweetie (LS), Mammoth Melting (MM), and Oregon Giant (OG)] and three sugar snap pea [Super Sugar Snap (3S), Cascadia (CA), and Sugar Sprint (SS) ]\} cultivated in 2014 (Year 1) and 2015 (Year 2). Dark grey bars indicate snow pea, whereas soft gray sugar snap pea. Means with same lowercase letters are not significantly different by Tukey's multiple comparisons test at $P \leq$ 0.05 . Average and error bars $(\mathrm{sE})$ of four replications; $1 \mathrm{~kg} \cdot \mathrm{ha}^{-1}=0.8922 \mathrm{lb} /$ acre. 
$[P \leq 0.05$ (Table 1$)]$. The variation in climatic environmental conditions is the main cause for those differences, associated with the population adjustment performed in Year 2, since higher planting density encourages vegetative growth due to increased competition for light, water and nutrients. Even though we had $62.5 \%$ less plants in Year 2, the weather-based irrigation management provided adequate conditions for plant growth, matching the high yield obtained in Year 1 . The relationship between proper water management and high yield is well known in the literature (Fougereux et al., 1997). For plant height and SSC, there were no significant year and cultivar interactions $[P>0.05$ (Table 1$)]$; only independent effects of years or cultivars.

'Little Sweetie' produced the highest total fruit yield in 2014 and 2015 compared with all other cultivars at 15,442 and $14,32 \mathrm{l} \mathrm{kg} \cdot \mathrm{ha}^{-1}$ $[P<0.0001$ (Fig. 2)], respectively. In Year 1, 'Oregon Giant' and 'Super Sugar Snap' had similar total yields of 10,775 and $9760 \mathrm{~kg} \cdot \mathrm{ha}^{-1}$, respectively, that were lower than 'Little Sweetie' and greater than 'Mammoth Melting' and 'Sugar Sprint' $[P<0.0001$ (Fig. 2)]. A similar trend was recorded in Year 2 with 'Oregon Giant' and 'Super Sugar Snap' total yields at 10,803 and $12,511 \mathrm{~kg} \cdot \mathrm{ha}^{-1}$, respectively $[P<0.0001$ (Fig. 2$)]$. Typical yields for edible-pod peas are 4000 to $5000 \mathrm{~kg} \cdot \mathrm{ha}^{-1}$ in Australia (Beckingham, 2001), 5600 to 7800 $\mathrm{kg} \cdot \mathrm{ha}^{-1}$ in California (Gaskell, 1997), 1370 to $3960 \mathrm{~kg} \cdot \mathrm{ha}^{-1}$ in New Mexico (Guldan and Martin, 1998) and 6000 to $10,000 \mathrm{~kg} \cdot \mathrm{ha}^{-1}$ in Illinois (Grimmer and Masiunas, 2004). The main reason for the higher yield is probably associated with between-row spacing. According to Gaskell (1997), single trellis rows are usually spaced $6-\mathrm{ft}$ apart, since this is the smallest spacing that will still accommodate a tractor for spraying and cultivation. Within the row, seeds are spaced every 3 to 4 inches for an estimated population of 49,000 to 75,000 plants /ha. Some small-scale growers plant their rows closer together and use hand operated spray equipment (Gaskell, 1997). Soil fertility also plays an important role on edible-pod pea production. Our study succeeded the sunn hemp cultivation as a cover crop, increasing the organic matter content and the nitrogen availability. Similar results were found by Grimmer and Masiunas (2004).

Fruit marketable yield for all cultivars ranged from $77.19 \%$ to $93.32 \%$ of the total yield in 2014 and 2015. 'Mammoth Melting' had the lowest percent marketable yield at $77.19 \%$, which was lower than 'Little Sweetie', 'Cascadia', and 'Sugar Sprint' in 2014 and lower than all cultivars evaluated in $2015[P<$ 0.0001 (Fig. 2)]. All other cultivars besides Mammoth Melting had similar marketable yields, ranging from $83.72 \%$ to $93.32 \%$ of total fruit yield. 'Mammoth Melting' and 'Sugar Sprint' marketable yields were over shadowed by the low total fruit yields (Fig. 2). Poor performance of 'Mammoth Melting' and 'Sugar Sprint' was likely due to the excess of over-mature fruit caused by temperature stress. To avoid over-mature fruit, the crop should be harvested every other day during peak production. The low total yield of 'Mammoth Melting' and 'Sugar Sprint' (Fig. 2) does not make these cultivars potential candidates for tropical regions such as the U.S. Virgin Islands.

The study performed in Year 2 (2015) produced taller plants $[113.9 \mathrm{~cm}$ (Table 2)], probably because of different environmental conditions. 'Mammoth Melting' presented the highest plant height in Year 1, showing a significant difference when measurements were taken at $85 \mathrm{DAP}$ and reaching a final height of $168.4 \mathrm{~cm}[P<$ 0.0001 (Table 2)]. Plant height for 'Super Sugar Snap' was lower than 'Mammoth Melting' but higher compared with other cultivars at 76 and 85 DAP $[P<0.0001$ (Table 2)]. 'Sugar Sprint' had the lowest height at both 76 and 85 DAP, measuring 53.0 and $55.6 \mathrm{~cm}$, respectively. Plant height may be an important consideration for growers because taller plants are easier and thus faster to manually harvest than shorter plants. In general, short plants are developed primarily for mechanical harvest, specifically green pea cultivars. However, plant height does not positively correlate to yield since 'Mammoth Melting' was the tallest cultivar in this study $(168.4 \mathrm{~cm})$ and produced the second lowest yields $\left(4249 \mathrm{~kg} \cdot \mathrm{ha}^{-1}\right)$ ('Sugar Sprint' yields were lower than 'Mammoth Melting' in 2014 and 2015); compared with 'Little Sweetie' that was on average $51.96 \%$ shorter, and $337.07 \%$ higher yielding (Table 2 ; Fig. 2). The fact that greater plant height does not necessarily correlate

Table 2. Plant height and soluble solids concentration for 2 years (2014 and 2015) at different days after planting (DAP) and six cultivars of edible-pod peas \{three snow pea [Little Sweetie (LS), Mammoth Melting (MM), and Oregon Giant (OG)] and three sugar snap pea [Super Sugar Snap (3S), Cascadia (CA), and Sugar Sprint (SS)]\}.

\begin{tabular}{|c|c|c|c|c|c|}
\hline \multirow[b]{2}{*}{ Factor } & \multicolumn{3}{|c|}{ Plant ht $(\mathrm{cm})^{\mathrm{z}}$} & \multicolumn{2}{|c|}{ Soluble solids concn (\%) } \\
\hline & $56^{y}$ and $53^{x} D^{x} P^{w}$ & $76^{y}$ and $73^{x}$ DAP & $85^{y}$ and $90^{x}$ DAP & $72^{y}$ and $73^{x}$ DAP & $82^{y}$ and $87^{x}$ DAP \\
\hline \multicolumn{6}{|l|}{ Year } \\
\hline 2015 & $66.8 \mathrm{~b}$ & 103.9 & $113.9 \mathrm{a}$ & $10.2 \mathrm{a}$ & 10.7 \\
\hline \multicolumn{6}{|l|}{ Cultivar } \\
\hline LS & $65.4 \mathrm{c}$ & $82.6 \mathrm{~d}$ & $87.5 \mathrm{~d}$ & 9.2 & $9.8 \mathrm{~b}$ \\
\hline $3 S$ & $83.7 \mathrm{~b}$ & $129.5 \mathrm{~b}$ & $148.3 \mathrm{~b}$ & 9.7 & $11.1 \mathrm{a}$ \\
\hline CA & $63.0 \mathrm{c}$ & $96.9 \mathrm{c}$ & $105.2 \mathrm{c}$ & 9.2 & $10.9 \mathrm{ab}$ \\
\hline SS & $40.8 \mathrm{~d}$ & $53.0 \mathrm{e}$ & $55.6 \mathrm{e}$ & 9.8 & $10.7 \mathrm{ab}$ \\
\hline
\end{tabular}

${ }^{\mathrm{z}} 1 \mathrm{~cm}=0.3937$ inch.

y2014 (Year 1).

×2015 (Year 2).

"Days after planting.

"Means followed by different letters, within columns and factors, are significantly different according Tukey's multiple comparisons test at $P \leq 0.05$. 
to higher yield in pea production is important when selecting a cultivar for tropical conditions. Plant heights in this study were $19.62 \%$ higher on 'Little Sweetie', 35.72\% on 'Oregon Giant', $42.8 \%$ on 'Cascadia' in Years 1 and 2 compared with Strang et al. (2011); they were also higher than the 75 to $90 \mathrm{~cm}$ range indicated for 'Oregon Giant' (Baggett and Kean,
1992) and $75 \mathrm{~cm}$ for 'Cascadia' (Baggett and Kean, 1993).

Fruit SSC varied from $9.1 \%$ to $9.8 \%$ in Year 1 and from $9.8 \%$ to $11.1 \%$ in Year 2 (Table 2). SSC increased over time for all cultivars in both years $(P>0.05)$. Cultivar data were significant only on 82 and 87 DAP (Year 2), with 'Super Sugar Snap' presenting the highest value
(Table 2). The fruit SSC increased $17.28 \%$ on average in Year 1 (over $10 \mathrm{~d}$ ) and only $2.99 \%$ in Year 2 (over $14 \mathrm{~d}$ ), probably due to the difference in the environmental conditions between years (Table 2). Although there was no significant difference in Year 1 in fruit SSC among cultivars, the sugar snap cultivars were only $2.74 \%$ higher than the snow pea
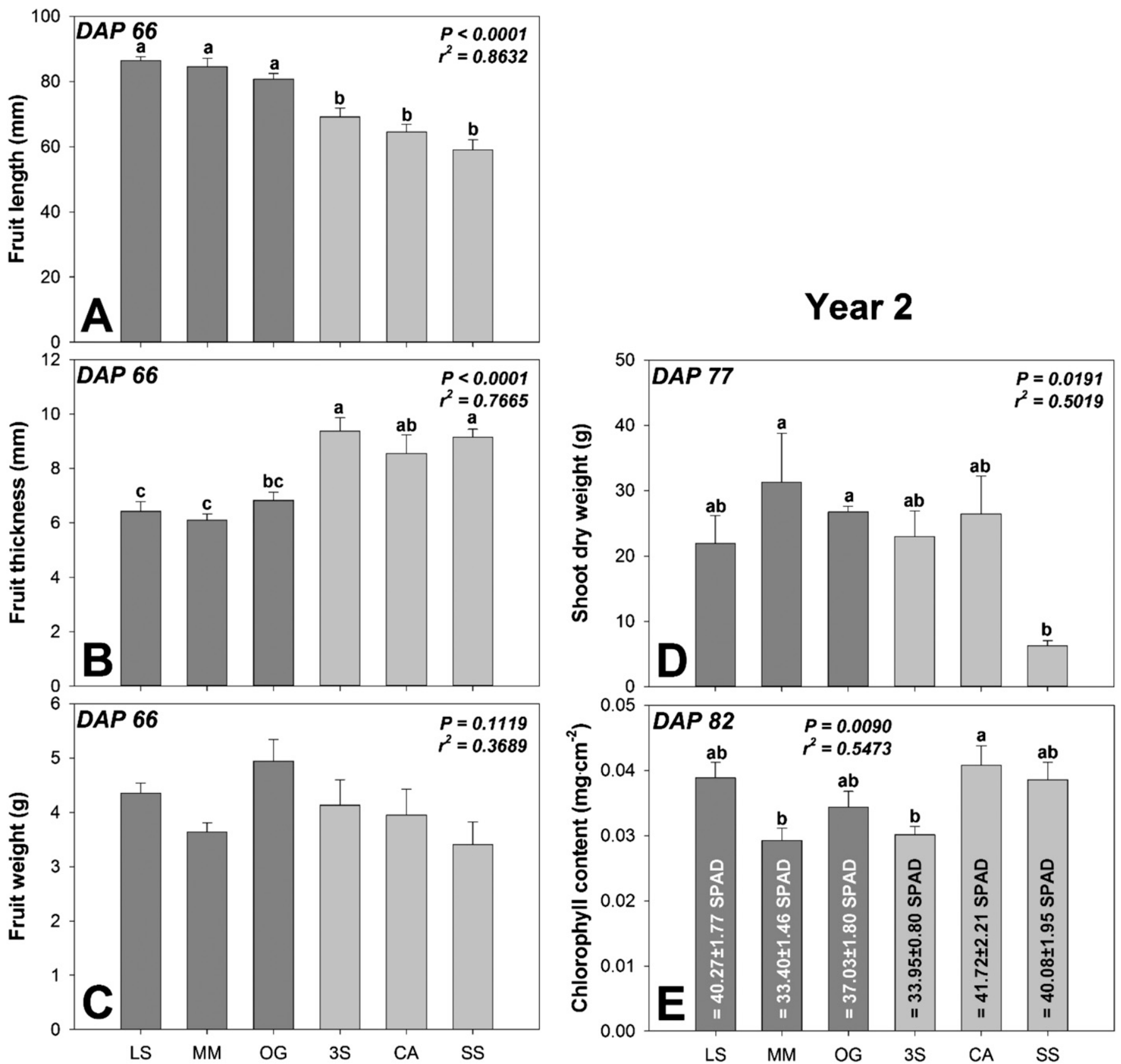

Fig. 3. (A) Fruit length, (B) fruit thickness, (C) fruit weight, (D) shoot dry weight, and (E) chlorophyll content of six cultivars of edible-pod peas \{three snow pea [Little Sweetie (LS), Mammoth Melting (MM), and Oregon Giant (OG)] and three sugar snap pea [Super Sugar Snap (3S), Cascadia (CA), and Sugar Sprint (SS)] \} cultivated in 2015 (Year 2). Data collected at 66,77 , and $82 \mathrm{~d}$ after planting (DAP). The conversion to SPAD units (index of relative chlorophyll content) was performed according to the calculations of Zhu et al. (2012). Dark grey bars indicate snow pea, whereas soft gray sugar snap pea. Means with same lowercase letters are not significantly different by Tukey's multiple comparisons test at $P \leq$ 0.05. Average and error bars (SE) of four replications; $1 \mathrm{~mm}=0.0394 \mathrm{inch}, 1 \mathrm{~g}=0.0353 \mathrm{oz}, 1 \mathrm{mg} \cdot \mathrm{cm}^{-2}=0.0328 \mathrm{oz} / \mathrm{ft}^{2}$. 
cultivars. In Year 2, the sugar snap pea was $6.51 \%$ sweeter than the snow pea (Table 2). It is not clear if these differences in SSC are useful in comparing cultivars without data from sensorial analysis. 'Little Sweetie' presented the highest yield, but the lowest SSC. If the cultivar recommendation is solely based on yield, then Little Sweetie can be indicated; but Little Sweetie had the lowest SSC $[P \leq 0.05$ (Table 2)]. More studies are needed to correlate edible-pod pea SSC with consumer acceptance to provide more information for growers selecting a cultivar.

The three snow pea cultivars presented the highest fruit length, ranging from 81 to $86 \mathrm{~mm}[P<0.0001$ (Fig. $3 \mathrm{~A})]$. The opposite happened with the fruit thickness, with the sugar snap pea being on average $28.5 \%$ larger $[P<$ 0.0001 (Fig. 3B)]. These results clearly show the standard morphological differences across the cultivars, since snow pea present long and flat pods while snap pea short and thick pods. These differences support the idea that larger fruit are not necessarily correlated with higher total yield. The snow pea presented a wider fruit but in general was lighter compared with the sugar snap pea. There is no trend on fruit weight $[P>0.05$ (Fig. 3C)]. Because of the larger pod, Baggett and Kean (1992) indicated that 'Oregon Giant' is best suited for use by home gardeners.

The shoot dry weight was on average 78.5\% lighter on 'Sugar Sprint' than 'Mammoth Melting' and 'Oregon Giant' $[P \leq 0.05$ (Fig. 3D)]. The poor performance of 'Sugar Sprint' is the result of the low biomass accumulation, probably because of the negative effects of temperature on stimulating plant growth. 'Sugar Sprint' produced less than other cultivars according to Strang et al. (2011), but the authors did not evaluate shoot dry weight to compare.

'Mammoth Melting' and 'Super Sugar Snap' had the lowest chlorophyll content compared with the other cultivars $[P \leq 0.01$ (Fig. $3 \mathrm{E})]$. This was probably the result of early crop senescence. The low chlorophyll content on 'Mammoth Melting' support the low yield obtained by this cultivar, since chlorophyll is the plant cell organelle responsible for photosynthesis, and consequently, productivity. However, no relationship was found between the low value on 'Super Sugar Snap' yield or the other variables evaluated. The reason for this variation is unknown.

\section{Conclusions}

It is possible to grow edible-pod peas in the cooler months on the island of St. Croix in the U.S. Virgin Islands. Results of this experiment indicate that both snow and sugar snap pea cultivars have potential as a specialty high-value crop. Even though there is high yield variability among cultivars, yields greater than those reported in temperate regions can be achieved using the management practices described in this publication. Of the cultivars tested, our results indicate that Little Sweetie was the highest yielding edible-pod cultivar evaluated within the environmental and geographical conditions of this study for two consecutive years.

\section{Literature cited}

Baggett, J.R. and D. Kean. 1992. 'Oregon Giant' edible pod pea. HortScience 27:853-854.

Baggett, J.R. and D. Kean. 1993. 'Cascadia’ snap pea. HortScience 28:1195-1196.

Beckingham, C. 2001. Snow peas and sugar snap peas. 22 Apr. 2015. <http:// www.dpi.nsw.gov.au/_data/assets/ pdf_file/0006/126339/Snow-peas-andsugar-snap-peas-Agfact-H8.1.35.pdf $>$.

De Ron, A.M., J.J. Magallanes, O. Martínez, P. Rodiño, and M. Santalla. 2005. Identifying superior snow pea breeding lines. HortScience 40:1216-1220.

Ferrarezi, R.S., S.K. Dove, and M.W. van Iersel. 2015. An automated system for monitoring soil moisture and controlling irrigation using low-cost open-source microcontrollers. HortTechnology 25:110-118.

Fougereux, J.A., T. Doré, F. Ladonne, and A. Fleury. 1997. Water stress during reproductive stages affects seed quality and yield of pea (Pisum sativum L.). Crop Sci. 37:1247-1252.

Gaskell, M. 1997. Edible-pod pea production in California. 1 Apr. 2015. <http:// anrcatalog.ucdavis.edu/pdf/7233.pdf>.

Grimmer, O.P. and J.B. Masiunas. 2004. Evaluation of winter-killed cover crops preceding snap pea. HortTechnology 14:349-355.

Guldan, S.J. and C.A. Martin. 1998. Interseeding snap pea into stands of chile pepper reduces yield of pea more than that of Chile. HortScience 33:660-662.

Godfrey, R.W. and P.J. Hansen. 1996. Reproduction and milk yield of Holstein cows in the US Virgin Islands as influenced by time of year and coat color.
Archivos Latinoamericanos de Produccion Animal 4:31-44.

Gonzalez, J.E., M. Angeles, D. Comarazamy, N. Ramirez, and C. Tepley. 2007. Origins of the Caribbean rainfall bimodal behavior. Proc. 87th Amer. Meteorol. Soc. Annu. Mtg. Paper 4A.5. 4 Apr. 2016. <https://ams. confex.com/ams/pdfpapers/118594.pdfs.

Gross, K.C., C.Y. Wang, and M. Saltveit. 2014. The commercial storage of fruits, vegetables, and florist and nursery stocks. U.S. Dept. Agr., Agr. Res. Serv., Agr. Hdbk. No. 66. 15 June 2015. <http://www.ba. ars.usda.gov/hb66/contents.html>.

Harmsen, E.W. 2012. Technical note: A simple web-based method for scheduling irrigation in Puerto Rico. J. Agr. Univ. Puerto Rico 96:235-243.

Intellicast. 2015. Historic weather report. 22 Apr. 2015. <http://www.intellicast.com/ Local $/$ History.aspx?location $=$ usvi0003 $>$.

Kahn, B.A. and W.A. Nelson. 1991. Row arrangement can affect yield and pod distribution pattern of trellised snow peas. HortScience 26:532-534.

Kottek, M., J. Grieser, C. Beck, B. Rudolf, and F. Rubel. 2006. World map of the Köppen-Geiger climate classification updated. Meteorologische Zeitschrift 15:259-263.

Pavek, P.L.S. 2012. Plant guide for pea (Pisum sativum L.). 15 June 2015. <http://plants. usda.gov/plantguide/pdf/pg_pisa6.pdfs.

Strang, J., C. Smigel, J. Pfeiffer, J. Snyder, and D. Slone. 2011. Pea variety evaluations, p. 2123. In: Fruit and vegetable research report. Univ. Kentucky Agr. Expt. Sta. Bul. PR-626.

U.S. Department of Agriculture (USDA). 1998. Soil survey of the U.S. Virgin Islands. 4 Apr. 2016. <http://www.nrcs. usda.gov/Internet/FSE_MANUSCRIPTS/ puerto_rico/PR690/0/VI.pdf>.

U.S. Department of Agriculture (USDA). 2015a. Miami terminal prices as of 22 APR-2015. 22 Apr. 2015. <http://www. ams.usda.gov/mnreports/mh_fv020.txt>.

U.S. Department of Agriculture (USDA). 2015b. Web soil survey. 18 Sept. 2015. <http://websoilsurvey.nrcs.usda.gov>.

U.S. Department of Agriculture (USDA). 2015c. Upper Bethlehem scan site, U.S. Virgin Islands. 18 Sept. 2015. <http://www.wcc. nrcs.usda.gov/nwcc/site? sitenum=2123 $>$.

Williams, T.V. and W. Roberts. 2002. Is vegetable variety evaluation and reporting becoming a lost art? An industry perspective. HortTechnology 12:553-559.

Zhu, J., T. Tremblay, and Y. Liang. 2012. Comparing SPAD and atLEAF values for chlorophyll assessment in crop species. Can. J. Soil Sci. 92:645-648. 